\title{
An e-Readiness Assessment of ICT Integration in Public Primary Schools in Kenya Case of Nyeri County.
}

\author{
Rachael Njeri Ndung'u \\ Department of Computing \\ Sciences \\ University of Embu, Kenya
}

\author{
Florence Maweu, \\ Department of Computing and \\ Information Technology, \\ Kirinyaga University, Kenya
}

\author{
Joyce M. Mwenja \\ Department of ICT \\ Kirinyaga University, Kenya
}

\begin{abstract}
In primary schools, information and communication technologies (ICT) are widely seen as tools for enhancing learning. This expectation increases their rapid diffusion and adoption throughout developing countries. Despite the strong emphasis given to ICTs in education, little has been done to evaluate e-readiness as a factor that influences ICT integration in primary schools in Kenya. This study sought to evaluate e- readiness of ICT integration in public primary schools in Nyeri Central Sub-County, Kenya. The study adopted descriptive survey design. The targeted population was 376 subjects comprising of 375 teachers in the 23 public primary schools in Nyeri Central Sub-county and one Sub-county director of education. 11 schools were sampled through simple random sampling technique. The SCDE and the head-teachers of every school sampled were purposively selected. 66 teachers were randomly sampled, making the sample size of 78 respondents. Data collection was done using questionnaires, interview and observations. There was a response rate of $100 \%$. The results indicated moderate readiness in adopting ICT in public primary school in Nyeri Central Subcounty. This would be enhanced if the government would expedite the process of procurement and installation of the digital hardware and software in the schools and also, plan on how all public primary teachers would be re-trained on ICT application on the primary education curricula.
\end{abstract}

Keywords: ICT; e-Readiness; integration; primary schools; education; e-readiness

\section{INTRODUCTION}

The reasons for introducing Information and Communication Technology (ICT) in schools are four-fold: technology innovations, globalization of economy and information, knowledge based economy and society and increasing demand for education (Temba, 2013). The role of ICT in promoting economic growth and development has gained prominence globally. Economies are been transformed from industrial to knowledge-based where knowledge is recognized as a driver of productivity and economic growth (OECD, 2004; World Bank, 2008). It's expected that adopting and using ICT in schools would lead to significant expansion of education and academic outcomes which are beneficial to both teachers and students. When used appropriately, ICT can help to support the value of education by increasing access to education opportunities, raising quality of education by making learning and teaching an active process connected to real life (Zaman, Shamim \& Clement, 2011).

ICT integration to curricula requires physical infrastructure, technology expertise and emotional readiness for those who are bound to implement it. As a first, the Kenyan government is making efforts to initiate e-learning in public primary schools by connecting all public primary schools to the national electricity grid. These efforts are aimed to prepare the schools to adopt ICT.

Despite the strong emphasis given to ICTs in education by even publishing Kenya national ICT policy (2006), little has been done to evaluate e-readiness as a factor that would influence ICT integration in primary schools in Kenya. Minimal e-readiness evaluation or lack of it would mean starting the ICT integration process without facts of whether the schools have capacity for integration or whether the process would successfully complete as was intended. It was on this background that this study sought to investigate the question: what was the level of physical and technological readiness of ICT integration in public primary schools in Nyeri Central Sub-county?

\section{OBJECTIVES OF THE STUDY}

The purpose of the study was to investigate and evaluate the various factors and extent to which public primary schools in Nyeri Central Sub-county in Kenya were prepared for ICT integration to the education system (curricula and administrative activities).

The general objective of this study was to evaluate the ereadiness of ICT integration in public primary schools in Nyeri Central Sub-county. In order to get more on the ereadiness, the general objective was further divided into more specific objectives, which were:-

To evaluate the extent to which public primary schools' institutional infrastructure can accommodate ICT facilities;

To establish the level of preparedness of teachers in using ICT in teaching and learning in the classroom;

To evaluate other factors that would hamper effective ICT integration in public primary schools in Nyeri Central Sub-county.

The research was guided by the following questions:

To what extent are public primary schools ready to integrate ICT in their institutions?

What is the level of preparedness of teachers in using ICT on teaching and learning methods?

What are other factors that would hamper effective ICT integration in public primary schools in Nyeri Central Sub-county? 


\section{LITERATURE REVIEW}

\subsection{Technology Readiness}

Ouma, Awuor, \& Kyambo (2013) did a study on e-learning readiness in public secondary schools in Kenya, and he sought to check e-readiness in terms of teachers' competencies, perception and attitude towards ICT. The study was based on schools that the government had selected to fund and support ICT infrastructure development and teacher's training in ICT. Ouma et al. (2013) in their study concluded that teachers were moderately ready for e-learning and that there were individuals who may need to be acculturated into the elearning system before they were said to be at the expected state of readiness for e-learning. They also found out that policy makers and other education stakeholders had a crucial role to play in enhancing greater engagement in a technologydriven teaching-learning environment. However, while Ouma et al. (2013) study was based on five secondary schools that were government sponsored to improve e-learning, this current study is evaluating e-readiness in public primary schools which are not receiving special ICT funds to improve e-learning from the government.

\subsection{Institutional Infrastructure Availability and Readiness}

In a study done in Kenya to evaluate the level of ICT investment in the education sector, Hennessey et al. (2010), while reviewing literature stated that the level of investment in ICT in education in Kenya reflects the recognition in the national ICT policy of the need for Public-Private Partnership (PPP) in addressing key development challenges in the country. Towards strengthening adoption and use of ICT in the education sector in Kenya, an ICT unit has been established at the Ministry of Education, Science and Technology (MoEST)'s head office to ensure systematic efforts are made. In this respect, the Government of Kenya, through MoSET plays a coordinating, overseer and mobilization role in bringing together key stakeholders in the ICT in education sector.

\subsection{Institutional Infrastructure Availability and Readiness}

In a study done in Kenya to evaluate the level of ICT investment in the education sector, Hennessey et al. (2010), while reviewing literature stated that the level of investment in ICT in education in Kenya reflects the recognition in the national ICT policy of the need for Public-Private Partnership (PPP) in addressing key development challenges in the country. Towards strengthening adoption and use of ICT in the education sector in Kenya, an ICT unit has been established at the Ministry of Education, Science and Technology (MoEST)'s head office to ensure systematic efforts are made. In this respect, the Government of Kenya, through MoSET plays a coordinating, overseer and mobilization role in bringing together key stakeholders in the ICT in education sector.

\subsection{Perceived Gap}

Reviewed studies have shown the need for adopting technology in the education sector. This adoption has to take place in all levels of education, starting from primary schools to higher institutions of learning. The ICT integration process are under-way but there is still unanswered question, are primary schools ready to adapt to technological aspects of teaching and learning? Could there be issues that are supposed to be addressed before integration starts? A study conducted by Hennessey et al. (2010) pointed out a summary of factors derived from a survey previously done. They noted that majority of teachers were ill equipped to effectively integrate ICT in classroom. The main challenges for teachers interviewed were lack of adequate number of computers, educational applications, training, policy and strategy on how integration should be done.

Not much is documented about ICT integration readiness in primary schools in Kenya. It is in this context the researcher wished to investigate the extent to which teachers were prepared for ICT in the classroom, the ICT infrastructure availability and access and generally how well prepared the public primary schools in Nyeri Central Subcounty are in adopting ICT in their education system.

\section{RESEARCH METHODOLOGY}

\subsection{Research Design}

The research was guided and conducted using the descriptive survey research design. Descriptive survey research designs are used in preliminary and exploratory studies to allow researchers to gather information, summarize, present and interpret for the purpose of clarification (Orodho, 2002).

\subsection{Geographical Description of the Study}

This research study was conducted in Nyeri Central SubCounty, Kenya. Nyeri central sub-county is located in Central region, in Nyeri County, Kenya. Nyeri County constitutes six sub-counties; Nyeri Central, Othaya, Tetu, Kieni, Mathira and Mukurwe-ini. The Nyeri Central Sub-county has 23 public primary schools. A sub-county director of education is in charge of education in the sub-county. All primary school heads in the sub-county account to the SCDE.

\subsection{Target Population}

The study targeted 375 teachers and one (SCDE) in Nyeri Central Sub-county. This gave a target population of 376 subjects. The SCDE gave the progress of e-learning readiness in the sub-county; the teachers who participated gave the information on their e-readiness, how they utilize computer technology and any challenges faced in their individual schools.

\subsection{Sample Size and Sampling Technique}

This study used simple random sampling method to sample 11 schools, which were used as representative of the population of public primary schools in Nyeri Central Sub-county. In every school that was sampled the head-teacher was purposively selected and six (6) other teachers were randomly sampled. The Sub-county director was also purposively sampled making the sample size of $[1+11+(6 * 11)]=78$ respondents. The seven teachers sampled per school were deemed a well representative sample.

\subsection{Data Collection Procedures}

The research study was a quantitative research. Quantitative data collection techniques used includes: online surveys, and questionnaires.

\section{Methods of Data Analysis}

The primary data, after collection, was processed and analyzed. This was essential for a scientific study and for ensuring that we have all relevant data for making contemplated comparisons and analysis. This involved processing of data, which consisted of editing, coding, 
classification and tabulation of collected data so that it was amenable to analysis. Percentages, frequency distributions were used to analyze the collected data with an aid of Statistical Package of Social Sciences (SPSS v20.0).

\section{DATA PRESENTATION \& ANALYSIS}

\subsection{Response Rate}

There were 77 questionnaires that were handed to all respondents. The researcher visited all eleven schools sampled and sought audience first to the head of schools. This was important to the researcher to explain the reason of the research and that the respondents been sought were teachers in those schools, the head teacher inclusive. Then the head of schools distributed the questionnaires randomly to the teachers who duly filled the forms, as the researcher waited. This method of questionnaire distribution gave a 100\% response rate. All the 77 questionnaires were filled up. There was also a scheduled interview with the sub-county director of education, which took place at his office. The interview was scheduled for 15 minutes. The response was also very positive since he answered all questions asked and even gave more explanations as of ICT status in the sub-county.

\section{SUMMARY, CONCLUSIONS AND RECOMMENDATIONS}

The study was to evaluate e-readiness of ICT integration in public primary schools in Nyeri Central Sub-county. Integrating ICT in primary education sounds an appealing method to address access and quality education challenges facing Kenyan education system. This study therefore was investigating e-readiness in very specific areas: institutional infrastructure development, teachers' competencies, funding and effects of governing ICT policies.

On the area of institutional infrastructure, it was found that despite all sampled schools having permanent buildings and electricity, the other key issues like security proofing within the schools premises has to be addressed for a successful ICT adoption. The issues that the research brought out as gaps were lack of ICT facilities (computers, internet, and syllabus content), lack of security, lack of buildings to secure computers and laptops and lack of ICT support staff.

It was found out that the teachers in Nyeri Central Sub-county were in the process of preparing themselves for ICT integration. Majority of the respondent showed regular computer access and their ICT skills were also averagely fair with majority of respondents aged below 40 years having attended the basic ICT classes. It was found-out that none of the respondents had ICT pedagogical integration training.

On other e-readiness considerations, the government would be funding the ICT project for all public primary schools in the country, but it was noted from the research done that other stakeholders like the parents of those schools should fund support and maintenance of the ICT facilities. It was also noted that the ICT support staff, should be government employees and not school board of management employees.

Another consideration was on policy, where it was noted that the national ICT policy (2006) has not taken affect as the guiding principal in schools, where the schools were supposed to demonstrate their ICT preparedness regarding infrastructure development, human resource development. It was found out this was because of lack of funding from the government.

Success in integrating ICT in a classroom setting is heavily dependent on teachers, investments in infrastructure to support a curriculum, the formation of practical ICT skills as well as pedagogical initiatives such as computer-assisted instruction. Evaluating e-readiness of ICT integration in public primary schools was guided by national ICT policy (2006), which acknowledges specific challenges as lack of policy and regulatory framework, inadequate infrastructure and insufficient skilled human resources.

\subsection{Discussions}

\subsubsection{Institutional infrastructure}

The findings from the study demonstrated that institutional infrastructure development requires urgent improvement in order to adequately support ICT facilities like cabling, that would in turn enhance connectivity of the network and internet, providing secure environment for e-learning. It was notable that all schools sampled demonstrated availability of electricity and permanent buildings. It was also demonstrated that, $62.3 \%$ of the respondents felt parents should fund security of the ICT infrastructure as stakeholders of the schools while the government should bear the cost of constructing computer rooms.

\subsubsection{Teachers competency}

The technical experience and computer literacy among teachers was found to be fair since $46.8 \%$ (36) of respondents access computers regularly. None of the sampled teachers demonstrated training on ICT application in curricula. The study however, revealed that teachers' attitude towards ICT was very positive and they were willing to acquire computing skills if at all the government would expedite the ICT pedagogical integration training sessions.

\subsubsection{Other factors hampering e-readiness}

Other factors that were brought out by the study that would enhance ICT integration to primary education system were funding and implementation policies. Other stakeholders like the parents have a responsibility of making sure that ICT integration to primary education is successful. Their participation would be in making sure that the installed ICT infrastructure and accessories were secure and well maintained as was demonstrated by $62.3 \%$ (48) and $68.8 \%$ (53) respondents respectively. This participation means they are expected to fund maintenance of the ICT facilities, while the government funds the entire installation of ICT facilities and mapping them to curriculum taught so as to take advantage of the technology.

The study also revealed that $46.8 \%$ (36) respondents were not aware of the Kenya national ICT policy (2006) and how it affects ICT integration in the primary education. There was mixed reactions from respondents in relation to the government policy of introducing laptops to junior primary classes. As was demonstrated by $56 \%$ (44) of respondents felt it was a good policy and $18.18 \%$ (14) respondents felt it a very poor policy citing lack of prioritizing teachers training on the side of the government. The researcher observed failure of the government through MoSET to sensitize the schools on the various polices they had formulated and also they had failed to follow the progress of certain issues raised by the policies at the school level.

Considering the responses of the respondents who felt laptops for junior primary pupils was misplaced, suggestions like computer training in primary schools should start at higher classes like standard six, seven and eight and not standard one, two and three, were fronted, giving reasons that junior pupils were yet to value laptops as serious gadgets 
for learning with, and often they would take them as playing toys.

\subsection{Conclusions}

In order to know whether the public primary schools in Nyeri Central Sub-county are ready for ICT-based teaching and learning, there was a need for an evaluation of e-readiness. From the findings of the study it can be concluded that public primary schools in Nyeri Central Sub-county are reasonably ready to integrate ICT with the primary school curricula despite many challenges.

\subsubsection{Institutional infrastructure}

There is an urgent need to improve institutional infrastructure development so as to support ICT facilities like cabling that would enhance connectivity of the network and internet and provide a secure environment for e-learning. Individual schools should take initiative to make such developments. Types of buildings, availability of electricity and security within schools were prerequisite measures of e-readiness as far as infrastructure development is concerned, and as the national ICT policy (2006) anticipates.

\subsubsection{Teachers competency}

The findings of the study revealed that primary school teachers were fairly versed with computer literacy, with those aged below 39 years having undergraduate degree as their highest qualification. This illustrated that teachers are e-ready even though they scored nil on ICT application into curricula. It was also revealed that teacher's attitude towards ICT was very positive. However, their computer skills could not be translated to teaching with and through technology. There is a dire need for these teachers to be retrained on ICT application in the classroom. MoSET should plan for the pedagogical training sessions of all primary school teachers as a way of improving the numbers of skilled human resource whose mandate would be to implement teaching and learning through ICT in classrooms.

\subsubsection{Other factors hampering e-readiness}

As the government promised the acquisition of both hardware and installation of digital content, it should show a deliberate process to expedite the procurement process. Further, the

\section{REFERENCES}

[1] Andoh, B. 2012. An Exploration Of Teachers' Skills, Perceptions And Practices Of ICT In Teaching And Learning In The Ghanaian Second-Cycle Schools, Contemporary Educational Technology 3(1), 36-49

[2] Balanskat, A., Blamire, R., \& Kefala, S. 2006. The ICT impact report. European Schoolnet.

[3] Cassim, K. M., \& Obono, S. E. 2011. On the factors affecting the adoption of ICT for the teaching of word problems. In Proceedings of the World Congress on Engineering and Computer Science (Vol. 1, pp. 19-21).

[4] Chigona, A., \& Chigona, W. (2010, June). An Investigation of Factors affecting the Use of ICT for Teaching in the Western Cape Schools. In ECIS.

[5] Chrysostomou, M. and Mousoulides, N. 2009. Teachers' Beliefs about the Adoption of New Technologies in the Mathematics Curriculum. Proceedings of CERME 6, pp. 1270-1279 study has shown that policy makers and other education stakeholders have a crucial role to play in enhancing greater engagement in a technology-driven teaching-learning environment. As Hennessey, et al. (2010) observed in their study, the level of investment in ICT in education in Kenya reflects the recognition in the national ICT policy of the need for Public-Private Partnership (PPP) in addressing key development challenges in the country.

Finally, to successfully integrate ICT in public primary schools the government should hasten to establish an ICT integration framework to guide the integration process and further, review primary education curriculum to include technological aspects that would assist efficient and effective use of ICT in teaching and learning in the classroom. As an urgent government policy, to build capacity needed for a smooth implementation process, teachers should retrained on how to apply ICT in teaching.

\subsection{Recommendations and further work}

It can be recommended that all public primary schools infrastructural facilities need to be improved to accommodate installation of ICT facilities. This should be a joint venture of the schools BOM and other schools' stakeholders.

Teachers service commission (TSC), should plan to retrain all public primary school teachers on the use of ICT in the classrooms so as to support teachers implement the same swiftly.

There is need to review the entire primary education curricula so as to take advantage of new technological aspects for all classes. The digital content as the software to be installed on the computers should bear the revised curricula. KICD are responsible for the revision of curricula and are the same who are preparing the digital content to be used. Until when this content will be installed in schools would on know it merits. It would be too early to criticize the digital content.

The government through MoSET should hasten the procurement of ICT devices their installations and also installation of digital content (software) for all public primary schools.

Since the study covered only public primary schools in Nyeri Central Sub-county, and e-learning is been introduced in the whole country of Kenya, further study of the level of ereadiness should be extended to all primary schools in the country both public and private.

[6] Ford, D. M. 2007. Technologizing Africa: On the bumpy information highway. Computers and Composition, 24(3), 302-316.

[7] Hennessy,S. Harrison,D. and Wamakote,1. 2010. Teacher actors Influencing Classroom Use of ICT in Sub-Saharan Africa: Itupale Online Journal of African Studies, 2 (2010) 39-54 39.

[8] Hennessy, S., Ang'ondi, E., Onguko, B., Namalefe, S., Harrison, D., Naseem, A., \& Wamakote, L. 2010. Developing the Use of Information and Communication Technology to Enhance Teaching and Learning in East African Schools: Review of the Literature: The University of Cambridge. Aga Khan University, Nairobi Kenya.

[9] Jones, A. 2004. A Review of the Research Literature on Barriers to the Uptake of ICT by Teachers. UK: Becta.

[10] Kashorda, M., Waema, T., Omosa, M., \& Kyalo, V. 2007. E-Readiness Survey of Higher Education 
Institutions in Kenya: A Study Funded by Partnership for Higher Education in Africa.

[11] Khan, H. Hasan, M. \& Clement, K. 2012. Barriers to the introduction of ICT into education in developing countries: the example of Bangladesh International Journal of Instruction, 5 (2) 61-80

[12] Kothari, C.R. 2004. "Research Methodology Methods \& Techniques", Second Edition, New Delhi: New Age International publisher, P.55.

[13] Kumar, N., Rose, R.C. and D'Sliva, J.L. 2008. Teachers' Readiness to Use Technology in the Classroom: An Empirical Study. European Journal of Scientific Research. 21(4), pp. 603-616.

[14] Lumumba, P. 2007. A Survey of Challenges Facing Elearning at Public Secondary Schools: A Case Study of the NEPAD Pilot Project in Schools in Kenya. Unpublished M.ED Project of the Catholic University of East Africa.

[15] Maruti, S. J. 2011. E-learning readiness among public primary teacher training colleges in Kenya (Doctoral dissertation).

[16] Mulwa, A. S., \& Kyalo, D. N. 2013. The Influence of Principals', Teachers' and Students' attitude On Readiness To Adopt E-learning In Secondary Schools in Kitui District, Kenya. European Scientific Journal, 9(5).

[17] Ncunge, D. Sakwa, M \& Mwangi, W. 2012. User's perception on ICT adoption for education support in schools: A survey of secondary school teacher's in Thika District Kenya, International Journal of Humanities and Social Science 2(10) 17-29

[18] Nzuki, D. 2014. Factors Influencing ICT Integration in Teaching-A literature Review.

[19] OECD \& World Bank. 2004. Korea and the KnowledgeBased Economy: Making the Transition.

[20] Orodho J. A. 2002. Techniques of Writing Research Proposals and Reports in education and Social Sciences. Nairobi: Masola Publishers.

[21] Ouma, G. O., Awuor, F. M., \& Kyambo, B. 2013. Evaluation of E-Learning Readiness in Secondary Schools in Kenya.

[22] Pelgrum, W. J., \& Law, N. 2003. ICT in education around the world: Trends, problems and prospects. Unesco, International Institute for Educational Planning.
[23] Ncunge, D. Sakwa, M \& Mwangi, W (2012). User's perception on ICT adoption for education support in schools: A survey of secondary school teacher's in Thika District Kenya, International Journal of Humanities and Social Science 2(10) 17-29

[24] Nzuki, D. (2014). Factors Influencing ICT Integration in Teaching-A literature Review.

[25] OECD \& World Bank. (2004). Korea and the Knowledge-Based Economy: Making the Transition.

[26] Orodho J. A. (2002). Techniques of Writing Research Proposals and Reports in education and Social Sciences. Nairobi: Masola Publishers.

[27] Ouma, G. O., Awuor, F. M., \& Kyambo, B. 2013. Evaluation of E-Learning Readiness in Secondary Schools in Kenya.

[28] Pelgrum, W. J., \& Law, N. 2003. ICT in education around the world: Trends, problems and prospects. Unesco, International Institute for Educational Planning.

[29] Sang, G., Valcke, M., Van Braak, J. and Tondeur, J. 2009. Factors support or prevent teachers from integrating ICT into classroom teaching: A Chinese perspective. Proceedings of the 17th International Conference on Computers in Education. Hong Kong: Asia-Pacific Society for Computers in Education. pp. 808-815.

[30] Temba, John, ed. 2013. 'ICT Policy and Framework, Four volumes, Ministry of Education, Science and Technology': ICT Vision.

[31] Tondeur, J., Valcke, M., \& Van Braak, J. 2008. A multidimensional approach to determinants of computer use in primary education: Teacher and school characteristics. Journal of Computer Assisted Learning, 24(6), 494-506.

[32] Zaman, M. Shahim R., \& Clement K. 2011. Trends and issues to integrate ICT in teaching learning for the future world of education. International journal of Engineering \& Technology 11(3) 114- 119.

[33] Zhang, J. 2004. Using ICT to prepare learners for the 21st Century: The perspectives of the eastern APEC economies. APEC Summit on Educational Innovation: "Striking Balance: Sharing Practice from East and West" Beijing. 